\title{
Curió Valente: representações de gênero em competições de pássaros canoros ${ }^{*}$
}

\author{
Flávia de Mattos Motta**
}

\begin{abstract}
Resumo
Este artigo descreve uma prática extremamente popular e tradicionalmente masculina em Florianópolis: os torneios de pássaros canoros. A etnografia das provas de "Fibra de Curió" ou "Curió Valente" pretende demonstrar as representações de gênero presentes numa competição canora de aspecto agonístico, na qual um macho deve intimidar e subjugar o outro através do canto. $\mathrm{O}$ "curió valente" é "um lutador" (que não toca fisicamente seu adversário). Aquele que emite o maior número de cantos vence a prova atestando a sua virilidade e sua superioridade de macho lutador sobre os demais participantes. O interessante é que há uma profunda identificação entre o pássaro e o seu dono, e o desempenho do pássaro repercute sobre a identidade, $e$ particularmente sobre a masculinidade, do próprio dono. Essa etnografia evidencia não apenas o aspecto representacional do gênero, mas também o seu aspecto relacional e circulacional. $\mathrm{O}$ que potencializa a masculinidade em jogo nas provas é a relação. Gênero aparece aí como sendo construído reciprocamente na relação macho/fêmea tanto quanto nas relações entre masculinos $e$ femininos.
\end{abstract}

Palavras-chave: Gênero, Masculinidade, Representações, Curió, Luta.

\footnotetext{
* Recebido para publicação em janeiro 2007, aceito em setembro de 2007.

*** Doutora em Ciências Sociais pela UNICAMP. Bolsista PRODOC no PPGASUFSC.mottaflavia@bol.com.br
}

cadernos pagu (30), janeiro-junho de 2008:199-229. 
Curió Valente

The Brave Curió:

Gender Representations in Song Birds Competitions

\begin{abstract}
This paper describes a very popular and traditionally male practice in Florianopolis: the song birds' tournaments. The ethnography on the "Curió Nerve" or the "Curió Braveness" contests intends to demonstrate gender representations that are present on sing birds competitions of agonistic aspect in which a male is expected to intimidate and subjugate another male by his own chant. The "brave curió" is "a fighter" (that does not have any physical contact with his opponent). The one that produces more chants wins the competition, attesting his virility and the male-fighter superiority over the other contestants. The interesting point here is that there is a profound identification among the bird and his owner, and the bird performance reverberates on the identity, and particularly on the masculinity of the owner. This ethnography makes evident not only the representational aspect of gender, but also its relational and circulational aspect. The element that gives potency to the masculinity in dispute on these contests is the relation. Gender appears here as reciprocally built on relations of male/female animals and on relations among masculines and feminines.
\end{abstract}

Key Words: Gender, Masculinity, Representations, Curió, Contest. 
Flávia de Mattos Motta

Muita gente não entende, mas eu prefiro um curió a um pit-bull: o risco é menor e o prazer, muito maior. (Áureo) ${ }^{1}$

Este trabalho segue uma linha teórica para a qual as representações de gênero - o próprio pensamento da diferença, remetido à diferença sexual - impregnam toda a práxis simbólica de um dado grupo humano. Gênero está definido como as categorizações ou classificações a respeito do que quer que seja objeto do pensamento humano - seres, coisas, pessoas, eventos segundo representações nativas de masculino e feminino. ${ }^{2}$ Tais classificações, baseadas na diferença masculino/feminino, no limite, à simbólica da diferença sexual, tendem a reproduzir a forma como se dão e são pensadas as relações de gênero na vida social - expressando relações de poder.

Se tudo, na prática simbólica, pode ser classificado como masculino ou feminino, também as representações sobre animais veiculam representações de gênero (Motta, 2002b). Neste texto, veremos como práticas relativas a pássaros canoros em Florianópolis estão impregnadas das representações de gênero nativas. $^{3}$

Os torneios de pássaros canoros são uma prática extremamente popular e tradicionalmente masculina não apenas

1 Ver Curió, Canto que encanta: apaixonados pelo canto do pássaro criaram uma sociedade em Florianópolis, hoje a maior do gênero na América do Sul (Diário Catarinense, 7/01/2001).

2 Referencial teórico sugerido por Strathern (1988).

3 Trabalho apresentado na V RAM. Reunião de Antropologia do Mercosul Antropologia em Perspectivas. Grupo de Trabalho XII - Sentidos do gênero: masculinidades, feminilidades, sexualidades (Coordenação: Fabíola Rohden e Flávia de Mattos Motta), Florianópolis, 30 novembro a 03 de dezembro de 2003. Na verdade, este trabalho é uma parte muito resumida de um capítulo de minha tese de doutorado (Motta, 2002a). Em se tratando especificamente desse capítulo da tese, devo agradecimentos especiais à minha professora Mariza Corrêa, com quem "tudo começou", e à minha orientadora, Guita Debert, que incentivou minha "imaginação antropológica" acerca de animais e passarinhos. 
Curió Valente

em Florianópolis, mas em todo o litoral catarinense. Meu estranhamento de estrangeira e meu olhar de antropóloga foram, desde que vim morar em Florianópolis há doze anos, despertados e desafiados por uma decantada paixão do manezinho ${ }^{4}$ pelo curió, que torna "normal" à cena urbana a circulação de homens portando gaiolas (como fazem os surfistas com seus cachorrões). O questionamento acerca dos significados dessas práticas exigia uma "etnografia do curió", que fui desenvolver no "Curiódomo da Ilha" da "Sociedade Amigos do Curió" (SAC). Para tanto, acompanhei as provas ocorridas em Florianópolis durante o Torneio da "Temporada de 2001" (setembro a dezembro).

A etnografia no Curiódromo restringiu-se a um tipo de prova que me pareceu mais importante porque muito concorrida, prestigiada pelos aficionados, e porque envolve muito claramente a questão da masculinidade e da relação entre masculinidades $e$ entre masculino e feminino. Refiro-me à prova de "Fibra de Curió", também chamada de "Curió Valente". Existem outros tipos de provas envolvendo curiós e outros tipos de pássaros com os quais também são realizadas provas de "fibra", como é o caso do "Coleirinha" e do "Trinca-Ferro" (este último conhecido também como "Tia Chica").

Vejamos então, resumidamente, como se organiza a prova "Fibra de Curió". Numa manhã de domingo, previamente agendada, no centro de um ginásio construído com essa finalidade, forma-se um círculo com as gaiolas colocadas lado a lado (cerca de 120 gaiolas), cada uma delas contendo um pássaro competidor. Durante 10 a 15 minutos (dependendo da etapa da prova), os pássaros são observados por juízes que contam (marcam) quantos cantos cada pássaro deu naquele tempo. Cada gaiola é observada por um juiz. Geralmente atuam vinte juízes ao mesmo tempo. Portanto, só podem ser marcados vinte pássaros de cada vez, a contagem ou marcação é feita de vinte em vinte

4 Como é chamado o homem "típico" nativo de Florianópolis, descendente de açorianos. 
Flávia de Mattos Motta

gaiolas. Feita a primeira contagem de cantos dos 120 pássaros, são selecionados os quarenta curiós que mais cantaram. Tira-se da roda os que foram derrotados. Organiza-se, a seguir, uma roda menor com as 40 gaiolas que restaram e novamente os juízes procedem a uma nova contagem de cantos cronometrando 15 minutos de 5 em 5 - contam cinco, depois cinco, e, novamente, mais cinco minutos. Os trinta melhores, isto é, os pássaros que entoaram o maior número de cantos (entre 130, 120 até 70, 80 cantos) são classificados (do trigésimo a primeiro lugar) e são premiados, recebendo um troféu.

\section{O embate: o enfrentamento entre dois valentes}

Em minhas observações no Curiódromo, dei preferência às competições de fibra envolvendo curiós. Há torneios também de coleirinha e de um outro pássaro canoro chamado trinca-ferro ou tia Chica. Dentro dos torneios de Curió, optei por seguir a modalidade "Fibra de Curió" em detrimento das de "Canto Livre" (ou "Peito de Aço") e "Canto Florianópolis", por ser a primeira aquela que mais enseja teorizações (nativas) de gênero (além de ser a prova mais importante e mais prestigiada). Nas provas de Canto livre e Canto Florianópolis, estão em jogo o virtuosismo dos pássaros. O pássaro canta sozinho mostrando sua habilidade de executar o canto livre ou a modalidade local chamada "Canto Florianópolis" (segundo informantes, uma das mais belas do Brasil), em que o pássaro demonstra muito especialmente a capacidade de repetição.

Seu Carlos, um freqüentador assíduo que me recebeu na primeira ida ao Curiódromo, fornece algumas informações sobre o que acontece entre os passarinhos na prova Fibra de Curió e como os homens a entendem:

Fibra de curió. É a modalidade mais concorrida hoje, aqui no estado, no Rio Grande, no Paraná, no Rio, São Paulo. Fibra de Curió é o Curió Valente. As gaiolas, você pode olhar ali, se você botar a gaiola... então fica com menos de 
Curió Valente

trinta [centímetros] uma da outra, então ele fica cantando na cara do outro. [E por que é valente? Ele fica disputando com o outro?] Ele disputa com o outro no canto. Não é feito briga de abrir gaiola ${ }^{5}$ e brigar... faz o outro correr na voz, no canto. Então volta e meia tem um ali que chac chac - correu -, enquanto o outro massacrar ele no canto. ${ }^{6}(\ldots)$ Claro, ele quer cantar mais que o outro, entendeu? (...) Provar que é melhor que o outro, porque, na própria mata, o curió, ele manda num raio muito grande de área. Ele e a fêmea estão naquele território ali. O curió escuta... a dez km de distância ele escuta um outro cantar, então se vier outro curió novo para a área dele, aí eles vão para a briga. E se ele correr, ele sai do terreno e o outro fica com a fêmea dele. Normalmente é assim. É a lei da selva, né? (...) É ele sabe, e se o outro vai querer enfrentar, ele parte prá... prá briga...

Na modalidade fibra, também chamada "Curió Valente", menos que o virtuosismo, importa a valentia do pássaro. Segundo um informante ocasional no Curiódromo (um homem de cerca de 45 anos), o pássaro repetidor (que participa sozinho das outras provas) "Não pode vir para a roda. Ele não é valente!... Porque esse aqui [apontando para os pássaros da roda], ele é lutador". Nessas provas, o pássaro compete lado a lado com os outros. As

5 Um informante falou-me sobre rinhas feitas "antigamente" com um pequeno pássaro canoro, o canário da terra. Ao falar dessa prática, o informante usou o tempo passado. Explicou-me como "faziam" as rinhas e que agora são feitas provas onde os canários se enfrentam "no canto" de forma parecida com as de fibra de curió diferindo apenas "na marcação". A julgar por um programa de televisão sobre ecologia apresentado por uma emissora de televisão local, as rinhas de canário, embora proibidas, não pertencem de todo ao passado. A matéria mostrava vários canários apreendidos pelo Ibama, salvos de rinhas praticadas em Santa Catarina.

6 Negrito aqui indica ênfase vocal do informante. Negritos em itálico representam ênfases adicionais da pesquisadora destacando palavras e expressões, que conforme será discutido adiante, revelam a dimensão agonística e metáforas de poder envolvidas nas representações acerca do curió. 
Flávia de Mattos Motta

gaiolas são penduradas em tripés dispostos em círculo (conforme a descrição feita pelo Sr. Carlos). A preparação do pássaro é fundamental. Antes de aprofundarmos a discussão a respeito do caráter agonístico do curió, é útil entendermos como se prepara um valente (e como isso é entendido pelos curiozeiros).

\section{Forjando fibra: a preparação do pássaro}

...o passarinho tem que ser treinado. Às vezes ele é bom, mas chega na hora e não canta. Tem que ser acostumado com gente.

(Informante ocasional. Curiódromo)

Não há campeão sem muito trabalho e cuidado da parte do dono ou tratador do passarinho. Mesmo que se conte com a melhor base genética e com um histórico de vitórias, preparação é a chave do sucesso do pássaro. ${ }^{7}$ Primeiro ele precisa estar acostumado com gente, movimentação e barulho, para não se intimidar com o torneio em si. Neste caso, as estratégias que incluem o "passeio" são fundamentais. Quando perguntava a respeito, todos enfatizavam a importância do passarinho familiarizar-se com movimento e que esse treino é muito bom para o animal, porque assim ele não se assusta. Um informante me conta o exemplo extremo de um conhecido que mora numa localidade muito distante na ilha e vem para o centro de ônibus com a gaiola e leva o passarinho para os bancos para fazer pagamentos. "O passarinho acostuma. O que assusta o passarinho é quando a gente não acostuma ele". Pergunto para o Sr. Carlos se o passeio serve para acostumar o passarinho: "Acostumar, para

7 Cabe observar que nunca ouvi nenhuma alusão ao fator "sorte". Uma única ocasião em que esse fator foi aludido (indiretamente) ocorreu quando alguém comentou que um certo passarinho não estava ido muito bem. Berenice mencionou uma planta que é popularmente conhecida por trazer sorte: "tem que dar arruda para ele". (Ao que um senhor replicou: tem que dar maconha! Diante de minha expressão de surpresa, logo me informaram a respeito da ração que inclui semente de linho cânhamo.) 
Curió Valente

ele perder o medo do... de coisa assim, de carro, de guardachuva, gente de chapéu. (...) E ele perde o medo de tudo!"

No Curiódromo, conheci Áureo, um homem de 30 anos que me foi apresentado como jóquei. ${ }^{8}$ Diante do meu espanto, ele explicou-me que era isso mesmo, jóquei de passarinho. Um sócio da SAC, paga-lhe para que trate de três dos seus curiós. Todos os dias, Áureo leva, de ônibus de linha, uma gaiola com um dos pássaros para a escola onde trabalha (serviços de manutenção). Áureo explica-me como é o serviço de jóquei: "passeia com o passarinho, muda a alimentação, vê como ele agiu na roda, e o que ele precisa." Em seguida, pergunta-me se eu sei quais os "fundamentos do curió" e passa a enumerá-los, contando nos dedos: "banho, banho de sol, alimentação e passeio - esses quatro fundamentos ele não pude deixar de ter." Grande teorizador, Áureo destaca o papel de adestrador do jóquei, cujo esforço aprimora a valentia do pássaro:

A valentia vem do pai e da mãe ${ }^{9}$ [do pássaro], mas o jóquei que não dá sangue, não dá valentia." E logo dá um exemplo que explica que genética não é tudo (na formação de um campeão): "o Pelé é um campeão, mas o filho dele...

Outro aspecto importante na preparação do pássaro é aquele que diz respeito mais diretamente a gênero enquanto relação. Para se defrontar com outros machos, mostrando valentia, o pássaro precisa estar quente. ${ }^{10}$ Esse aquecimento é

8 E, só depois de encerrado o trabalho de campo no curiódromo, percebi que era o mesmo passarinheiro entrevistado numa matéria de jornal que arquivara $e$ que refiro na epígrafe deste artigo.

9 Mas essa bilinearidade não é equilibrada. Áureo complementa: "A fêmea impõe $70 \%$ da genética do pássaro".

${ }^{10} \mathrm{~A}$ associação entre a idéia de aquecimento e potencialização da masculinidade é recorrente em diversos contextos etnográficos e está freqüentemente associada a uma outra noção, que relaciona ativo/masculino e passivo/feminino. Françoise Héritier (1996) analisa a questão em Aristóteles (mostrando inclusive como o 
sazonal e relacional. É sazonal porque, logo após o inverno, após a muda de penas, ele ainda está muito frio, mas à medida que vai entrando a primavera e ele vai participando dos torneios ele vai se aquecendo. É relacional porque quem aquece o pássaro, é a fêmea, ou melhor, a relação entre macho e fêmea (administrada pelo tratador do passarinho, seja ele o seu dono, a mulher do dono, ou um jóquei).

Após a muda, o tratador começa a preocupar-se em aquecer seu pássaro, "fica trabalhando o passarinho" (Berenice), aproximando-o da fêmea. O momento e o tempo certos dessa aproximação são considerados fundamentais para o desempenho posterior do pássaro nos torneios. Berenice, esposa de um curiozeiro (que tornou-se uma "informante privilegiada" na SAC), assim explicou-me o mau desempenho do curió de seu marido na primeira prova da temporada: "ele botou muito cedo a fêmea!". Uma outra senhora (Rosinha), que me foi apresentada como uma "passarinheira" (e não simplesmente esposa de passarinheiro), parecia desconsolada com o mau desempenho de seu curió: "não sei se é muita fêmea ou pouca fêmea". As provas acontecem sempre aos domingos. A semana que antecede a prova é revestida de cuidados, rituais e procedimentos calculados (envolvendo a relação macho/fêmea), conforme narrou-me um competidor de cerca de 45 anos:

Na quarta-feira, põe a fêmea do lado [do macho, em gaiolas separadas]. Depois separa. Sábado, vai puxando a fêmea para perto. Aos pouquinhos... para não dar aquele choque térmico.

Pergunto espantada sobre o "choque térmico" e ele conta de um passarinho que ele teve quase morto em suas mãos por causa de um choque térmico. Desavisadamente juntou, sem o devido

modelo aristotélico se verifica na cultura ocidental contemporânea), contrastando com o modelo Sambia de construção de gênero. 
Curió Valente

cuidado, o macho e a fêmea. Só muito lentamente o pássaro se recuperou. Ele conclui: "Você tem que entender o passarinho!"

No dia da prova, evitado o "choque térmico", macho e fêmea vão juntos para o local do torneio, numa capa, chamada "capa-motel", que junta as duas gaiolas (impedindo entretanto que um pássaro passe para a outra gaiola, isto é, evitando a cópula). Assim, o pássaro, ao menos idealmente, chega ao curiódromo devidamente "aquecido". "Eles deixam do lado da fêmea aí ele trava e ele fica quente, tirou dali ele vai cantar o que sabe. Aí fica... fera mesmo." Na hora da prova, o curió é introduzido na roda enquanto a fêmea fica num recinto externo ao da prova, chamado "guarda-fêmea".

O que define, entretanto, o desempenho do pássaro na prova não é apenas a relação deste com a fêmea, mas a relação entre os machos. Como explicou-me o Sr. Carlos, na vida selvagem, o curió canta para demarcar território e ele ouve um outro macho a quilômetros, então ele canta para mostrar que aquele território tem dono e que esse dono é valente. Por isso é que aquele outro informante disse que o curió fibra é "lutador": ele submete o outro macho pela força do canto. Através do canto, o curió amedronta aquele que disputa seu território, adversário este que, em tese, pode estar na mata, mas, nos torneios, está na gaiola ao lado. Aquecidos anteriormente e estimulados pela presença de outro macho, o curió fibra canta - e como canta: "tem passarinho que faz 100 cantos em cinco minutos!", disse-me um informante ocasional durante uma prova. Mas o animal tem lá suas idiossincrasias, mesmo bem trabalhado, às vezes ele não canta, ou canta menos do que tem capacidade.

\section{A dimensão agonística do "curió"}

Demorei muito para entender essa valentia/covardia na relação entre os curiós. Não conseguia entender a dimensão agonística do torneio, muito menos as categorias nativas que designavam a derrota. O "perigo" da prova, segundo os 
informantes indicavam, é que se o pássaro não tiver fibra, ele corre ou pia. Foram as mulheres que referi acima quem mais paciência (ou menos constrangimento) tiveram para me explicar essas categorias e situações que as mesmas designam. Especialmente Berenice me ouviu sempre com muita simpatia $e$ paciência, achando graça de minhas perguntas e equívocos $e$ esforçando-se em me fazer entender, por meio de exemplos, as explicações vagas ou insuficientes que outros me davam. Durante uma prova, diante de sua preocupação, eu pergunto se seu pássaro não está cantando, ao que ela responde:

Tá cantando, mas tá piando, acho que é muita fêmea. É que alguns precisam de mais fêmea, mas aí é ruim para o torneio porque se acostuma a estar com a fêmea em cima $e$ fica chamando ela, fica piando.

Há um controle por parte dos passarinheiros, mas principalmente da própria organização do torneio sobre esse aspecto do comportamento dos pássaros competidores. Se o pássaro pia, deve ser retirado da roda: "Tem que tirar antes que ele pie. Senão ele desasa, fica corrido. E, se ele desasa, 'acabou o passarinho'. Ele fica nervoso, aí ele desasa e corre. Trava ele" (Berenice). ${ }^{11}$

Um informante forneceu-me, de forma muito expressiva, explicações sobre as categorias correr e desasar:

- (I) Ele corre do canto do outro. Corre e grita: chac chac chac, desasa mesmo, que não sabe onde enfia a cabeça. [Imita com o próprio corpo o curió desasado.] (...) Chac chac chac, grita mesmo de medo... sem o outro pegar... só no canto do outro. (...) Deixa vir domingo. A senhora vai vir aqui, vai ver, vai ficar de olho, vai ficar aqui, daqui a

\footnotetext{
${ }^{11}$ As categorias nativas em itálico neste parágrafo aparecem em algumas falas como equivalentes ou sinônimas. Outras falas revelam significados mais precisos para cada uma delas.
} 
Curió Valente

pouco o chefe da roda: ó, o curió tal piou, brochou coitado: chac chac aí o dono vem e tira. E se deixar ali mais meia hora, ele vai pro fundo da gaiola e grita mesmo!

O informante que me disse que o curió valente é lutador, explicou-me porque o curió que pia deve ser retirado da roda: "o curió fibra, ele canta e luta. Ele humilha o outro. Quando o curió pia, ele pia como fêmea. O do lado [da gaiola ao lado] ganjeia ele. Aí trava, porque ele passa a ganjear aquele". ${ }^{12}$

Traduzindo: o Curió que pia na roda é um curió que foi vencido, humilhado pelo habitante da gaiola vizinha, cuja fibra, valentia, ou seja, masculinidade, submete a do outro e a subverte em feminilidade. O curió que pia, pia como fêmea. Uma vez feminizado, se não for retirado da roda, passa a ser "ganjeado" pelo seu vizinho (que está aquecido - pleno de fibra $e$ masculinidade). Não só ele pára de cantar e, portanto, de competir, como pára de estimular um terceiro curió que está na gaiola do lado oposto ao que estava o que "piou".

O curió que fica ao lado do que piou, isto é, que foi feminizado, fica travado, não canta mais, porque não precisa mais intimidar o macho que invade seu território, precisa, sim (se é agora uma fêmea que tem ao seu lado), ganjear a fêmea, dar início ao ritual de acasalamento. O curió derrotado - feito fêmea precisa se retirado da roda.

O caráter agonístico dos torneios de pássaros canoros é expresso muito claramente pelos informantes ao descreverem a

${ }^{12} \mathrm{O}$ verbo ganjear é êmico, uma espécie de termo técnico que designa a corte, uma exibição feita pelo macho à fêmea. Acredito que seja uma derivação do substantivo ganja (no Dicionário Aurélio: vaidade, presunção) assim como o adjetivo ganjento (vaidoso, presumido, engangento). Procurei, sem sucesso, o termo ganjear em vários dicionários, inclusive o "Dicionário da Ilha" (Alexandre, 1994), que só traz o adjetivo gangento (grafado com " $\mathrm{g}$ ") - pessoa convencida, gabola. O cruzamento, a cópula propriamente dita é designada pelo termo gala (substantivo feminino), que, no Dicionário Aurélio, aparece com o sentido de "fecundação do ovo" ou, como um termo chulo, do nordeste brasileiro, que designa sêmen, esperma. 
Flávia de Mattos Motta

"disputas" - tanto na mata como nos torneios. Retornemos às expressões usadas pelo Sr. Carlos:

Ele disputa com o outro no canto. (...) enquanto o outro massacrar ele no canto. [Ou] Provar que é melhor que o outro, (...) ele manda num raio muito grande de área. (...) aí eles vão para a briga. [E ainda] (...) e se o outro vai querer enfrentar, ele parte... prá briga...

Nessa briga - que não inclui o enfrentamento físico, mas apenas canoro -, um adversário não só massacra o outro, intimidando-o (vai para o fundo da gaiola), o que se verifica no seu físico (ele "desasa"), como ainda lhe tira a masculinidade, transforma-o em fêmea a ponto de passar a gangeá-lo (voltaremos a essa questão na próxima seção).

\section{De pássaros e homens}

É muito difícil a gente chegar... explicar tudo detalhadamente para a pessoa, às vezes, que não tem noção do... do todo, né, mas é uma arte ...precisa entender o passarinho, precisa conhecer o pássaro. Às vezes com essa fêmea ele não, não se adapta, daqui a pouco com outra ele vai dar certo. (...) Tem passarinho que se travar cedo no sábado, no domingo ele fica amojado, como a gente diz, ele não canta. $\mathrm{O}$ cara foi descobrindo que tinha que só travar às duas da tarde, às três da tarde, o outro já tem que botar na sexta, e assim vai, uma série de... (...) Então tem uma série de coisas que acontece com o passarinho. Até o dono descobrir... leva tempo! (Sr. Carlos)

A identidade entre homem e curió é inequívoca. O curió, especialmente o "curió-valente", preparado para torneios de fibra, incorpora atributos de masculinidade extremamente valorizados nesse contexto: valentia, fibra, poder e capacidade de enfrentamento e intimidação. Embora comparável com a identificação entre homens e galos em Bali observada por Geertz, 
Curió Valente

essa identificação entre homem/curió - mesmo que "inequívoca" aos olhos da pesquisadora - não atinge as proporções balinesas. ${ }^{13}$ Não há, no contexto que estudei - nem naquele do Curiódromo nem no folclore "mané" 14 ou "açoriano-brasileiro" -, o duplo sentido deliberado referido por Geertz (segundo ele, encontrado tanto na língua inglesa quanto na balinesa) - trocadilhos, piadas $e$ obscenidades assimilam homens e galos. Mesmo assim, embora não tão direta, tampouco facilmente identificável na linguagem cotidiana do homem nativo, a relação metafórica entre curió $e$ homem, evocando simbolicamente masculinidade, é inegável.

Voltemos aos exemplos dados anteriormente através dos quais entendemos o que é o "embate" entre curiós. Vimos que o risco envolvido na prova de fibra é o curió piar e correr. São significativas as falas de dois informantes reproduzidas anteriormente. O primeiro traduz a categoria correu, usando, como sinônimo, a palavra brochou, que, acredito que em todo o Brasil, no português popular, significa a perda de ereção. $\mathrm{O}$ segundo afirma que o pássaro não pode continuar na roda depois de piar, porque, feminizado, passará a ser ganjeado pelo curió valente que o submeteu. Em ambas as falas - mais que simples falas, exegeses -, aparece aquilo que se insinua de forma muito

${ }^{13}$ Referindo sugestão de Bateson e Mead, Geertz (1978:283-4) afirma que os galos eram vistos como "pênis, auto-funcionáveis, órgãos genitais ambulantes".

${ }^{14}$ Mané (ou manezinho) é a forma originalmente pejorativa de referir o homem nativo (equivalente a "matuto", "jeca"), embora mais recentemente se verifique forte tendência a uma revalorização dessa figura. Na mídia, especialmente, há um esforço de ressignificação (positiva) da figura do "mané", a exemplo do "Troféu Manezinho da Ilha" concedido, desde 1987, para personalidades destacadas e nascidas na Ilha (a partir de 2000, concedido também a empresas e para "Manezinhos Honorários", ou seja, pessoas nascidas fora da cidade). Sobre esse processo de ressignificação, o uso político da figura do "manezinho" (especialmente contra ambientalistas e a "esquerda gaúcha" na cidade) e o "aproveitamento" (ideológico, político e econômico) da figura do tenista Gustavo Kuerten desde sua vitória em Roland Garros (como o manezinho que deu certo), ver o quarto capítulo (A construção da figura do manezinho) do livro Cidade dividida (Fantin, 2000); ver também Rial (1994). 
Flávia de Mattos Motta

sutil em toda a questão do curió-valente: seu aspecto fálico, a metáfora fálica nele implicada.

É nesse sentido que se revela extremamente simbólica a história colhida por Francisco Pereira Neto, aqui reproduzida, na qual, uma mulher liberta os melhores pássaros do marido, ao descobrir sua infidelidade sexual (e por certo também afetiva $e$ relativa ao papel de provedor), que inclusive resultara em filhos. A mulher subtrai, assim, ao marido, aquilo que fazia dele um "campeão" $e$, se pensarmos o curió como metáfora fálica, promove uma castração simbólica.

Como as rinhas de galos - brasileiras e francesas (Teixeira, 1993) ou balinesas -, os torneios de curió são tradicionalmente "uma atividade pública de apenas um sexo, sendo o outro excluído total e expressamente" (Geertz, 1978:84). Até recentemente, as disputas de pássaros em Santa Catarina eram experiências de homossocialidade (androssocialidade, para ser mais precisa). Em localidades menos urbanizadas, ainda são exclusivamente masculinas.

Em geral, o gosto pelos pássaros canoros é despertado na infância. Alguns homens, como o marido de Berenice, nascido na praia da Armação em Florianópolis, tem a "doença" do curió desde pequeno, aprendida com o pai, também passarinheiro (embora Berenice ressalve que é o único filho a herdar o gosto do pai - nenhum de seus irmãos se interessam pelo assunto). Esse talvez seja o caminho mais tradicional para a adesão à prática. Seu Carlos, nascido em Criciúma, também é passarinheiro de longa data: "desde criança, 7, 8 anos, eu crio pássaros em gaiola". Um garoto de 19 anos, do Pantanal, bairro próximo ao centro de Florianópolis, que conheci ao acaso quando fui tirar cópias de fotos relativas ao curió também revelou-se um passarinheiro fervoroso e perguntei-lhe de onde vinha esse interesse, se aprendera com o pai. Ele disse que foi com um amigo de infância que era um aficionado. Alguns homens, ao falarem sobre a origem de seu interesse pela atividade, fazem menção aos efeitos terapêuticos do curió (relativos a doenças respiratórias, 
Curió Valente

especialmente bronquite), como é o caso do então presidente da SAC, Joselito Soares, que adquiriu o primeiro curió para curar a bronquite da filha. Joselito afirma que é uma "simpatia", pode não ter base científica, mas funcionou no caso de sua menina.

Se um homem é "passarinheiro", há uma profunda identificação psicológica entre ele e o animal (que pode ser um curió, um coleirinha ou um trinca-ferro). Assim como as glórias do passarinho cobrem seu dono de glória, o mesmo acontece com o fracasso. No primeiro torneio que assisti, vendo, em certo momento, a roda desfalcada, isto é, faltando gaiolas que ali estavam inicialmente, perguntei a um grupo de homens sentados próximos à roda o que aquilo significava, o que havia acontecido com aqueles participantes. Eles me explicaram, divertidos: "Correram!... Não sei se é os donos ou o passarinho [quem correu]. É que o passarinho corre e o dono fica com vergonha... Tem que ter um mínimo de noventa cantos..."

Quando o pássaro é campeão, seu dono também o é. ${ }^{15}$ Se o pássaro demonstra que tem fibra, isso repercute na própria imagem e identidade de seu dono. Nos torneios de pássaros, ao menos em certos momentos cruciais, a identidade entre o proprietário e o pássaro chega a ser incorporada pelo primeiro parece inscrita, ou dramatizada, no próprio corpo do homem, nas atitudes corporais. Quando o pássaro "pia”, o dono - cabisbaixo, ombros caídos - retira a gaiola quase escondendo-a com o corpo, carregando-a perto do chão - "Sai com ela no dedinho assim pendurado... sai prá ninguém ver!", como me disse um

${ }^{15}$ Vimos como a categoria "campeão" "é recorrente" na linguagem dos passarinheiros, determinando inclusive toda uma categoria, digamos, "onomástica". O interessante é que essa categoria também aparece recorrentemente "no resto" do campo desta pesquisa, isto é , fora do âmbito dos torneios de pássaros, utilizada correntemente para designar homens bemsucedidos. Maneca usa essa palavra quando refere-se ao tempo em que se considerava um bom provedor, exercendo profissões prestigiadas socialmente como motorista de ônibus e caminhoneiro: "eu já fui campeão" (ou "eu já tive um cartaz"). Quando fiz sua genealogia disse o mesmo do seu pai, afirmando "ele já foi campeão, tinha padaria, negócio próprio, mas deu para beber..."). 
Flávia de Mattos Motta

entrevistado [imita o gesto de quem estaria carregando uma gaiola pendurada no dedo mínimo, quase como que evitando "contágio"]. ${ }^{16}$ Quando o pássaro se sai bem, o dono o retira levando a gaiola, freqüentemente acima da cabeça, com a postura altiva, o peito inflado como que ciente de sua própria "fibra". Quando o pássaro é vencedor, o próprio homem o é. Como disse um outro associado comentando o orgulho que sente tendo um campeão: "É o ego da pessoa: enche o ego!"

Durante os torneios e nas falas a respeito do curió, observei uma constante comparação entre o pássaro e seu dono de forma a promover uma assimilação das qualidades de um pelo outro. É sintomático que a premiação seja dada para o dono e para o passarinho - ambos são nomeados no momento em que é dado o troféu. Até esse momento, o competidor sabe quantos cantos seu curió deu em cada rodada, mas não sabe o dos outros competidores. É só no momento da premiação que é revelada colocação de cada competidor. Os trinta primeiros lugares recebem troféus ${ }^{17}$ e a colocação dos mesmos é revelada à medida que são chamados pela ordem inversa, isto é, do trigésimo ao primeiro lugar. Os organizadores do evento anunciam cada

${ }^{16}$ No Curiódromo não acontece, mas a gozação pode ser grande em torneios alternativos como o observado por meu amigo antropólogo e, segundo um informante, também "no Rio de Janeiro".

${ }^{17}$ No Torneio dos Campeões, o último da temporada, foram dados, para os primeiros colocados, também aparelhos de som e uma televisão para o primeiro lugar. A supervalorização do curió na SAC ficou evidenciada pela maior distribuição de prêmios nas provas de curió do que para as de outros pássaros (coleira e trinca-ferro), o que gerou certa manifestação de protestos entre participantes dessas outras provas. $\mathrm{O}$ dono de um coleirinha premiado manifestou seu desagrado denunciando a distribuição de mais prêmios para os criadores de curiós, ponderando, quase aos gritos, "mas o coleirinha e o trincaferro é os passarinhos que dá mais dinheiro!". Esta frase revela uma situação semelhante à descrita por Santos (2001) envolvendo "cobus" e "broas" (ou seja, lavradores e garimpeiros), em que uns e outros consideram a sua atividade econômica mais vantajosa que a do outro: a vantagem alegada (por exemplo, diamantes não "enchem barriga" como feijão) repercute positivamente sobre a masculinidade. 
Curió Valente

premiado, fazendo, antes, uma apresentação do mesmo - falando às vezes do passarinho ("é um passarinho novo" ou "é defeituoso, mas eu acho o melhor, tem nome de craque de futebol"), às vezes do dono ("é alguém muito querido", "é um novato"). Outras vezes, a entrega da premiação enseja uma comparação aberta entre o pássaro e seu dono:

É muito canto! [Esse pássaro] É muito bom! ...E o proprietário do pássaro é melhor ainda! [Ou então] É o melhor pássaro, tem muita fibra e o dono tem mais fibra ainda: é o Mussum!

Às vezes a comparação entre homem e pássaro se dá de forma mais genérica, menos personificada na figura de um dono. No dia em que Berenice explicou-me sobre ganjear a fêmea, perguntei-lhe se deixavam que ele cruzasse com ela depois da prova. Ela disse que não, porque isso inutilizaria o passarinho para outras provas na temporada, pois "ele fica choco, fica femeado". Espanto-me, e ela conclui: "É que nem guri, quando quer uma guria! Depois que conseguiu...".

Os homens falam ordinariamente com seus pássaros. Num dos torneios que assisti, ao terminar a última marcação, um homem retira da roda a sua gaiola orgulhoso, olhando e falando embevecido com o seu curió. Deposita-a sobre a arquibancada num espaço vago entre mim um grupo de amigos seus (que já estão conversando animadamente compartilhando uma garrafa de cerveja). Escuto-o dizer ao passarinho: "Valeu! Obrigado por hoje!" Uma senhora me conta de um passarinho que o marido teve

que era ótimo, foi campeão em oitenta e nove, mas em 2000 ele [o marido] não trabalhou bem, então não tava bom. Não se saiu bem. Fez negócio com um cara que queria porque sabia que o passarinho era bom. Aí o passarinho foi campeão de novo. Ele diz, ele tem uma foto de torneio que ele ganhou [ela imita o gesto do marido 
Flávia de Mattos Motta

segurando com as duas mãos uma foto imaginária]: "Esse me deu alegria!". [Ela me conta também] Ontem ele sentou na frente do passarinho e ficou assim ó [sentado, as mãos apoiando o queixo, olhando para a gaiola]: "amanhã tu vais me dar uma alegria né?".

Num domingo, no início da temporada, esse passarinho não estava se saindo muito bem. Ela dizia então: "Hoje ele já chega [em casa] chutando a gaiola. Já chega xingando!". A esse respeito, torna-se muito sugestiva uma espécie de ato falho cometido por um informante. Esse homem explicava-me como é importante entender o passarinho: "É, o próprio nome do curió em tupi-guarani quer dizer amigo do homem, então o passarinho se adapta com a pessoa". E começa a falar como é importante conversar com o passarinho e como isso pode estimular o canto, pois "todo o animal quer carinho". Eu concordo argumentando que dizem que até as plantas se beneficiam com esse tipo de tratamento. Ao ouvir isso, meu interlocutor acrescenta, encerrando o assunto: "Até as plantas, que não falam, né? É verdade!" (ou seja: os passarinhos falam!?).

Mais uma vez citando e parafraseando Geertz, a relação entre esses homens e seus pássaros é mais do que metafórica. Como vimos, os homens dispensam muitos cuidados e dedicam muito tempo e trabalho a seu pássaro. É comum em Florianópolis vermos homens circulando a pé ou de bicicleta com uma gaiola ou mesmo a cena em que um homem se põe imóvel erguendo a gaiola em direção ao primeiro sol da manhã. Resta ainda o banho (que consiste em introduzir diariamente no interior da gaiola, preferivelmente no mesmo horário, uma cumbuca com água, a qual o passarinho utiliza para se banhar), a alimentação (bem equilibrada e dosada) e o passeio - além de toda a preparação para os torneios envolvendo a relação com a fêmea. "Tem que entender o passarinho". Quando me esforçava por compreender essa relação de "afinação" entre o dono e o passarinho, o sr. Carlos concluiu: "É, é uma arte" - a arte não se refere ao canto do 
Curió Valente

passarinho, mas à capacidade do dono (ou tratador) de entender o passarinho e propiciar as coisas certas - banho, passeio, alimentação adequadamente balanceada e "fêmea" (na duração, momento e freqüência certos).

Ao se referir à rinha de galo de "jogo" ${ }^{18}$, Geertz usa o adjetivo "absorvente". O adjetivo também cabe no caso dos torneios envolvendo pássaros canoros. Os participantes não usam o mesmo adjetivo, mas abusam do substantivo "paixão". Nos depoimentos que obtive, havia um empenho em transmitir-me o quão absorvente era aquela prática, caracterizando-a como "um vício", "uma doença", "uma cachaça", "um tóxico (...). Você vicia com o passarinho!". Em certas situações, pareciam querer prevenir-me, como se dissessem "isso pega". Num torneio em que me vi cercada de "informantes voluntários", um homem a quem já entrevistara anteriormente, passou apressadamente e gritou de longe: "Olha que ela vai virar passarinheira!". Ao que um rapaz que acabara de conhecer responde, também em tom jocoso: "Pelo menos curiosa ela é!" (Às vezes, talvez iludida, tive a sensação de encontrar, em Florianópolis, impressões de Geertz quanto aos Balinenses: "Em Bali, ser caçoado é ser aceito") (Geertz, 1978: 282).

\section{De homens e homens}

Após a prova, durante a apuração, é uma barulheira! Além dos pássaros que permanecem no ginásio, são os homens que "soltam cantos". A conversa é animada. O tom de voz é alto, a cerveja começa a correr. Formam-se grupos de homens que comentam o desempenho de seus pássaros $e$

\footnotetext{
${ }^{18}$ Creio que poderíamos apontar vários aspectos relativos aos torneios de pássaros canoros que nos permitiriam falar também em "jogo". Não creio, entretanto, ser esse o caminho mais fértil para a discussão. Em todo o caso, vale esclarecer, caso o leitor tenha a mesma curiosidade que eu tive ao iniciar o campo, não há apostas durante as provas ( $e$, segundo me informei, nada semelhante a um bookmaker).
} 
Flávia de Mattos Motta

assuntos gerais (Do diário de campo. Torneião. 16 de dezembro de 2001).

Mesmo nos torneios do Curiódromo onde vemos algumas poucas mulheres acompanhando maridos e namorados e uma ou outra participando com seu próprio curió, mesmo aí, há um reconhecimento de que aquela é uma atividade masculina, na qual a presença feminina é uma novidade ou uma excentricidade. Quando discuti esse assunto com Berenice, questionando sobre o interesse das mulheres pelo curió, ela me disse que muitas mulheres gostavam, "mas nos homens é doença". Mesmo comportando presenças femininas, prevalecem, no curiódromo, espaços de franca sociabilidade ${ }^{19}$ masculina - formam-se rodinhas de bate-papo descontraído, jocoso, muitas vezes, regadas a cerveja, especialmente no final das provas ou à medida que o final se aproxima, às vezes, incluindo um "churrasquinho" ou almoço na lanchonete da SAC. A relação entre os homens no curiódromo inclui amizade, emoção ${ }^{20}$, afeto e rivalidade. É sutil, mas é possivel perceber uma certa atitude corporal $e$ "vocal" característica dessas "rodinhas" só de homens. Anotei em meu diário vários fragmentos de conversas ouvidas involuntariamente ao circular pelo curiódromo. Não imagine o leitor que eu tenha ficado "pelos cantos", sorrateira, escutando conversas: há uma forma de conversar nessas rodas em que os homens parecem querer ser ouvidos fora da "rodinha" - os assuntos muitas vezes envolvem conhecimentos, valores éticos ou morais, expõem vantagens pessoais ou denigrem adversários e, em alguns casos, acionam linguagens que não vi usarem na minha presença (e que, creio não estar errada, performam masculinidade). São fragmentos de conversa do tipo:

${ }^{19}$ No sentido de Simmel (1983: 169): "a forma lúdica da sociação".

${ }^{20}$ Durante a premiação no Torneio dos Campeões, alguns homens foram às lágrimas quando foi feita uma homenagem especial a um sócio falecido durante a temporada, dono de vários campeões, e pai de um jovem curiozeiro, que, também em lágrimas, recebeu o troféu. 
Curió Valente

Eu não dou bola, né? Passou o passarinho, mas o dono é burro... [ou] Recebi uma proposta boa prá caralho! [ou ainda o seguinte diálogo]:

- ...se botou a fazer pega com o passarinho!

- Fazer pega, isso não se faz!

- Passear é uma coisa, mas fazer pega!...

Como nas rinhas de galo, também nos torneios de curió são os homens que se defrontam. No Torneião, um homem exultava num pequeno círculo de pessoas de que eu participava: "Os nossos estão cantando mais do que o Teimoso e o Popó. ${ }^{21}$ Hoje vai ter surpresa... vai inverter os poderosos!" Creio que "poderosos" nessa fala refere-se aos homens e não aos pássaros. Mas essa foi a única fala em que vi expressa mais claramente a disputa entre os homens. Em geral, o clima cordial, lúdico e de confraternização prevalece sobre a rivalidade dissimulada que envolve os homens e é inerente à disputa protagonizada por seus curiós.

É muito especialmente nos "negócios" que "os homens se defontam". Há uma questão subjacente à "paixão" pelo curió e que permeia os torneios: a econômica. $\mathrm{O}$ valor de troca dos pássaros, condicionado ao seu desempenho, excita desde os aficionados mais miúdos, participantes de pequenas provas não oficiais, até os que poderíamos, por contraste, chamar de "mais graúdos", donos de grandes campeões de torneios oficiais. Nestes últimos, os valores são comentados sob certo sigilo, como se o interesse econômico maculasse o mais autêntico sentimento dos participantes: a paixão pelo canto. Não obstante, freqüentemente à boca pequena, os homens se vangloriam em contar que seu curió recebeu uma boa oferta. Os "miúdos" falam em negócios envolvendo cerca de 300 reais, os graúdos, 20, 40 ou 70 mil reais. É o desempenho do pássaro nos torneios que determina a "cotação" de cada um no mercado de campeões. Há histórias fantásticas, como a de um grande campeão muito conhecido no

${ }^{21} \mathrm{O}$ que acabou não se confirmando na pontuação final. 
Flávia de Mattos Motta

Curiódromo trocado por uma casa em algumas versões e, em outras, "por um carro e dois apartamentos na praia".

No curiódromo, falar sobre dinheiro e valores dos pássaros é considerado inadequado. $\mathrm{O}$ assunto, ao menos quando introduzido por pessoas de fora (jornalistas, antropóloga), parece de mau gosto, não cai bem. Mas ele é constante. Quando perguntei diretamente ou assisti lideranças do curiódromo falarem à imprensa diretamente sobre os valores envolvidos em transações com pássaros, ouvi respostas do tipo "nós não gostamos de falar sobre isso" ou o que um famoso criador de pássaros disse num documentário de televisão (SBT) sobre o curió: "A importância não é o super-valor do pássaro, não vai ficar super-valorizado... É o ego da pessoa: enche o ego!". Mesmo assim, constantemente os próprios informantes introduzem o assunto (valor do pássaro) - faz parte da conversa sobre pássaros canoros. Mas, no curiódromo, freqüentemente ao demonstrar meu interesse em desenvolver mais detidamente o assunto, a conversa era evitada. Um informante desenvolvia entusiasticamente o tema, em dado momento, empenhando-se em me fazer entender o valor que aqueles pequenos pássaros podiam atingir, revelou-me, quase segredando, neste ponto da conversa, um negócio, divulgado "no Fantástico" 22 que teria se realizado recentemente envolvendo associados da SAC, em que um curió teria sido vendido por vinte $e$ nove mil dólares - o que conferia à sociedade a imagem de "clube de elite", onde "só tem magnatas".

É preciso frisar que negócios com passarinhos não precisam envolver cifras milionárias para serem considerados bons - para atingirem positivamente "o ego da pessoa" ou serem usados para "contar vantagens" - ou simplesmente lucrativos. O garoto que conheci quando fui fazer cópias, tendo, então, se revelado passarinheiro, contou-me que vendeu seu curió por trezentos reais - com o mesmo orgulho que aquele outro homem dizia que

${ }^{22}$ Programa de televisão líder de audiência que vai ao ar pela maior emissora brasileira todos os domingos, no horário nobre. 
Curió Valente

recebera uma proposta, digamos, para não repetir o palavrão, "extremamente vantajosa". Foi com alegria divertida e não menos orgulho que Berenice referiu os negócios do marido: "Entra tudo nesses rolos com passarinho! É carro, é vídeo, câmera de vídeo". E mostra-me a câmera de vídeo com que estivera gravando a participação do curió de seu marido.

A questão econômica permeia as práticas relativas aos pássaros canoros e, com toda a certeza, concorre para torná-las ainda mais absorventes - e masculinas. A minha hipótese é que "saber lidar com o dinheiro", saber negociar e tirar vantagem num negócio é também percebido como atributo moral masculino tanto quanto fibra e valentia. É possível que isso esteja simbolicamente ligado a associação entre masculinidade e o papel de provedor da família.

Nos negócios envolvendo pássaros canoros e através das histórias relativas a esses negócios, os homens estabelecem alianças e se defrontam. Egos e masculinidades se confrontam algumas se reforçam, enquanto outras saem fragilizadas do confronto.

\section{De mulheres e pássaros}

Talvez o leitor tenha sido iludido pelas várias referências que faço aqui a mulheres que conheci no Curiódromo. Na realidade, a presença feminina nos torneios é ínfima. ${ }^{23}$ Se em torneios mais populares e informais essa presença é claramente indesejada, no curiódromo, ela está longe de ser massiva - raramente vi mais do que três ou quatro mulheres no ginásio onde ocorrem as provas.

${ }^{23}$ A "presença" recorrente de mulheres neste capítulo sobre curiós deve-se antes de tudo ao sexo e mais particularmente à identidade de gênero da própria pesquisadora. Sendo aquele um espaço consagrado de androssocialidade, a conversa com uma mulher estranha e leiga no assunto pareceu-me freqüentemente desconfortável aos informantes do sexo masculino. Além disso, a exegese de certos aspectos da prática desemboca em temas relativos à sexualidade, o que também gera desconforto. Com as mulheres, esse tipo de assunto fluiu com mais tranqüilidade. 
Flávia de Mattos Motta

Em geral, havia uma ou duas apenas e muito freqüentemente não havia nenhuma além de mim. Algumas vão acompanhar maridos e namorados, mas acabam ficando na lanchonete no prédio ao lado.

No primeiro torneio que assisti, estava fazendo perguntas a um informante ocasional e perguntei-lhe alguma coisa sobre o interesse exclusivamente masculino por aquela prática. Ele me disse então que

Tem mulher sócia! Aqui tem uma passarinheira que tava com dor no coração! Olha ali ela. O marido é sócio e o passarinho é dela. Ela tava numa agonia! Fala com ela que ela vai te dizer [E me apresentou Rosinha].

Em outro torneio, conheci outra mulher, vinda do Paraná especialmente para o torneio, que, ao enviuvar, ficou com os pássaros do marido e resolveu continuar a prepará-los e competir com eles. Berenice não é considerada "passarinheira", mas participa ativamente do cuidado com os passarinhos do marido ("Eu é que cuido: dou banho, boto no sol... [E passeia?] Ô se passeio, tem que passear!"). Naquele documentário da rede de televisão SBT referido atrás, um criador de curiós assim respondeu à jornalista que lhe perguntava sobre a colaboração de sua esposa em seu empreendimento: "Todo o passarinheiro, toda a pessoa que gosta de passarinho, tem que ter a mulher do lado. Se ela não ajudar... Não adianta!" A jornalista então dirige-se à mulher do passarinheiro perguntando-lhe se a atividade dá mais prazer ou trabalho, ao que a moça responde: "Mais prazer do que trabalho, com certeza". Ouvi passarinheiros dizerem que "a mulher", no sentido de esposa, tem que gostar de passarinhos, mas um senhor foi muito veemente em dizer que muitas não gostam nada de terem seus maridos envolvidos com essa atividade. Berenice concordou enfaticamente.

Apenas no Torneião havia um número mais expressivo de mulheres. Neste dia, ao anunciar o primeiro lugar, o presidente da 
Curió Valente

SAC, Joselito Soares, sublinhou que o passarinho pertencia a uma mulher (embora a mesma não estivesse presente). E esta não foi a única mulher vitoriosa naquele Domingo: Soró, o curió de Rosinha, também ficou entre os cinco primeiros colocados. Mais receptivo à participação feminina (se comparado com o formato original desses torneios), o Curiódromo parece refletir as mudanças sociais observadas em locais mais urbanizados $e$ "modernizados", onde a mulher passa a ocupar espaços antes considerados masculinos - talvez mostrando, no plano simbólico, o que a mulher já vem mostrando na sociedade: que fibra $e$ valentia não são atributos exclusivos da masculinidade. Quando vi e fotografei Rosinha recebendo o troféu, depois de tanto "sofrimento", não pude deixar de pensar nela como uma "mulher de fibra".

Em Santa Catarina, o interesse e a presença de mulheres nesses torneios são novidades. Se alguns contextos ainda lhe são refratários, o curiódromo pareceu-me de grande receptividade - se não entusiasmada, ao menos resignada. $O$ discurso de encerramento do presidente da SAC, Joselito Soares, sublinhava a satisfação em observar que torneios de pássaros não são mais "Clube do Bolinha" e que mulher também "gosta de andar com a gaiola na mão".

Um senhor de setenta anos, julgando-me "mulher de passarinheiro", ao ver-me examinar os troféus expostos sobre a mesa antes de serem entregues aos classificados, abordou-me:

A senhora gostaria de ter um troféu desses? (...) Porque é um troféu que tá bonito, assim masculino e feminino, a mulher do passarinheiro que leva esse troféu para casa fica feliz de receber esse. A senhora que viu os outros, o que que a senhora acha? 
Depois fiquei sabendo que era ele mesmo quem fizera os troféus daquele domingo e por isso estava tão interessado no julgamento de uma mulher de passarinheiro. E não estava errado em - sendo fabricante e vendedor desses troféus - interessar-se pela opinião delas: várias vezes as vi comentar sobre a beleza dos troféus. O troféu daquele torneio era feito de metal, mas há os de cristal ou vidro, muito apreciado por elas pelo que pude entender. Um outro, feito de plástico ou algum tipo de resina, foi considerado inadequado por algumas informantes. ${ }^{24}$ Pelo que pude entender, para as mulheres, o troféu adquire um papel decorativo - ele tem que ser bonito, escultural, artístico para ser exposto em casa. Aquele senhor, com larga experiência em torneios de pássaros - em todo o Brasil -, revelou grande sensibilidade artística - senão literária - em articular num troféu e numa fala - aquilo que está no centro daqueles torneios, usando suas palavras: "assim, masculino e feminino".

\section{Considerações finais: um teatro absorvente}

A exemplo das touradas e da farra do boi, e segundo a sugestão de Vale de Almeida (2005), podemos pensar as provas envolvendo pássaros canoros, especialmente os de "fibra", como "teatros masculinos", não só como situação (tradicionalmente) de homossocialidade, mas principalmente a dramatização da masculinidade que aí ocorre. Mas, como já demonstrei a respeito da Farra do boi (Motta, 2002), cabe aqui também falar em "teatro de gênero": é a relação masculino/feminino, entre masculinidades $e$ feminilidades que são aí dramatizadas e pensadas.

Também está aí representado aquele pressuposto apresentado anteriormente segundo o qual masculinidade $e$ feminilidade não estão coladas a corpos fisica e genitalmente

${ }^{24}$ Embora o que ele representava tivesse sido amplamente elogiado por pessoas de ambos os sexos. Foi chamado "Guguinha", pois tinha um desenho em que um curió "segurava" (com a asa) uma raquete de tênis. Um homem me disse que achou "bacana", pois era uma homenagem ao Guga. 
Curió Valente

masculinos ou femininos. Fibra e valentia, atributos morais considerados masculinos têm que ser forjados. $O$ masculino aparentemente inscrito no corpo do macho pode dar lugar ao feminino como conseqüência de uma relação em que um macho, tendo potencializado sua masculinidade, domina e subtrai a do outro, fazendo-a fluir para feminilidade. É o caso da exegese que aquele informante forneceu-me quando me explicou que o pássaro que pia deve ser retirado da roda para evitar que o outro trave, pois passará a ganjeá-lo.

Neste ponto, é pertinente fazer uma comparação com as rinhas de galo - não as de Bali, mas as brasileiras descritas por Sérgio Teixeira. O autor afirma que estão aí em jogo atributos morais pensados como inerentes à masculinidade, tais como: coragem, brio e estoicismo. Fibra e valentia, categorias usadas pelos passarinheiros, também são atributos morais tradicionalmente masculinos e, mesmo sem o sangue derramado nos rinhadeiros, reforçam o caráter agonístico das provas de fibra de curió. Interessante que haja categorias similares. ${ }^{25}$ Segundo Teixeira, a pior derrota que um galista pode sofrer é a derrota sem brio, quando o galo pia de galinha, fazendo com que a luta se encerre: "Como a rinha é para galos e um virou galinha, seu término é automático" (Teixeira, 1993:211). Esses dois exemplos

${ }^{25}$ Tive notícias extremamente vagas a respeito de rinhas de galo em Santa Catarina. O rapaz que conheci quando fui fazer cópias de matérias de jornal sobre o curió chegou a dizer-me: "o manezinho adora rinha de galo", mas não obtive outras referências a respeito durante o trabalho de campo. Uma matéria de jornal dá notícias a respeito desta prática informando que o procurador-geral da República, Geraldo Brindeiro, atendendo pedido da Procuradoria da República, de Joinville, protocolou uma ação direta de inconstitucionalidade, no Supremo Tribunal Federal contra a lei aprovada pela Assembléia Legislativa do Estado de Santa Catarina em 2000 que autoriza a criação, exposição e competição envolvendo aves da raça "galus-galus". A lei autoriza e regulamenta rinhas de galo. Para o procurador de Joinville, Cláudio Cristani, autor da proposta encampada por Geraldo Brindeiro, "A lei fere o artigo 225 da Constituição Federal, que, entre outros itens, proíbe a crueldade com os animais". Ver: Brindeiro contra alei que autoriza rinha de galo. Florianópolis, A Notícia, 06-07-2001, p.A9. 
similares - do curió e do galo de rinha - ilustram muito eloqüentemente o aspecto relacional do gênero (masculino $e$ feminino se constroem via relação) e circulacional, a fluidez do gênero, como feminino e masculino, via relação, fluem de um pólo a outro. $\mathrm{E}$, conseqüentemente, como o feminino está presente no masculino e vice-versa - o que permite esse deslizamento.

Masculino e feminino, no pensamento da diferença (que perpassa as práticas descritas neste artigo), está presente o aspecto relacional do gênero. $\mathrm{O}$ que potencializa a masculinidade em jogo nas provas é a relação. De forma sutil, aparece aí gênero como sendo construído reciprocamente na relação não apenas macho/fêmea, mas na relação entre masculinos e femininos. Bem entendido que o "feminino" pode incluir um macho feminizado. Não só um macho é feito via aquecimento provocado pela fêmea e pelo estímulo do canto de outro macho, como também um macho pode ser feito fêmea se piar e correr a ponto de ser cortejado por outro macho.

Como as rinhas de galos - brasileiras e francesas (Teixeira, 1993) ou balinesas -, os torneios de curió são tradicionalmente "uma atividade pública de apenas um sexo, sendo o outro excluído total e expressamente" (Geertz, 1978). Até recentemente, as disputas de pássaros em Santa Catarina eram experiências de homossocialidade (androssocialidade, para ser mais precisa). No curiódromo, já se percebe atualmente a presença feminina, inclusive já existem algumas poucas "curiozeiras" (criadoras $e$ competidoras), mas em localidades menos urbanizadas, "humanos" participantes de torneios de curiós ainda são exclusivamente representantes do sexo masculino.

A "etnografia do curió" evidencia aquilo que escrevi em meu diário de campo quando fui pela primeira vez ao Curiódromo: "o curió é puro gênero" e, como tal, é metáfora de poder. Essa etnografia evidencia não apenas o aspecto representacional do gênero, mas também o seu aspecto relacional 
Curió Valente

e circulacional. $^{26}$ Segundo as explicações nativas, o que potencializa a masculinidade em jogo nas provas é a relação. Gênero aparece aí como sendo construído reciprocamente na relação macho/fêmea tanto quanto nas relações entre masculinos $e$ entre masculino e feminino - sendo que nem sempre "feminino" coincide com "fêmea" (fisiologia feminina). A masculinidade - de pássaro e de homens - é potencializada pelas relações e não é fixa nem permanente - aumenta, é subtraída, desloca-se, desliza, circula.

\section{Referências bibliográficas}

AlEXANDRE, Fernando. Dicionário da Ilha: fala e falares da ilha de Santa Catarina. Florianópolis, Cora Coralina, 1994.

CORRÊA, Mariza. O sexo da dominação. Novos Estudos CEBRAP (154), Jul/1999.

Fantin, Márcia. Cidade dividida. Florianópolis, Cidade Futura, 2000.

GeERTZ, Clifford. Notas sobre a briga de galos balinesa. In: GeERTZ, C. A interpretação das culturas. Rio de Janeiro, Zahar, 1978.

MotTA, Flávia de Mattos. Gênero e reciprocidade: uma ilha no sul do Brasil. Tese de Doutorado em Ciências Sociais, Universidade Estadual de Campinas, 2002a.

. O Sexo dos anjos: gênero e representações sobre animais no litoral catarinense. In: AlmEIDA, H. B. et alli (orgs.) Gênero em Matizes. Bragança Paulista-SP, Editora Universidade São Francisco. $2002 b$.

RiAL, Carmem Sílvia. Manezinho: de ofensa a troféu. Jornal da Fundação Franklin Cascaes, Florianópolis, jun/1994.

SANTOS, Bernadette Grossi dos. O reino da impura sorte: mulheres e homens, garimpeiros em Minas Gerais. Dissertação de Mestrado, Florianópolis, PPGAS/UFSC, 2001.

\footnotetext{
${ }^{26}$ Para uma argumentação teórica a respeito no sentido de que gênero "circula" (o que pode ser "verificado" empiricamente em diferentes sociedades), ver Corrêa, 1999; Motta, 2002a e 2002b.
} 
Flávia de Mattos Motta

SILVESTRE, Glauco. Curió, Canto que encanta: apaixonados pelo canto do pássaro criaram uma sociedade em Florianópolis, hoje a maior do gênero na América do Sul. Diário Catarinense, Florianópolis, 7 de Janeiro de 2001.

SIMMEL, Georg. Sociabilidade: um exemplo de sociologia pura ou formal. In: MoraES FILHO, Evaristo de. Georg Simmel: Sociologia. São Paulo, Ática, 1983 (Grandes Cientistas Sociais;, 34).

STRATHERN, Marilyn. The gender of the gift: problems with women and problems with society in Melanesia. Berkeley, University of California Press, 1988 [O Gênero da Dádiva. Problemas com as mulheres e problemas com a sociedade na Melanésia. Campinas-São Paulo, Editora da Unicamp, 2006, (tradução: André Villalobos)].

TeIXEIRA, Sérgio Alves. Brigas de galo e expressão ritual de atributos morais de gênero. In: FONSECA, Cláudia (org.) Fronteiras da cultura. Porto Alegre, Ed. Universidade/UFRGS, 1993.

VAlE DE ALMEIDA, Miguel. Senhores de Si: uma interpretação antropológica da masculinidade. Lisboa, Fim de Século Editora, 1995. 